\title{
The lingering question of menthol in cigarettes
}

\author{
Ahmad Besaratinia $\cdot$ Stella Tommasi
}

Received: 23 June 2014/ Accepted: 13 November 2014/Published online: 22 November 2014

(C) Springer International Publishing Switzerland 2014

\begin{abstract}
Tobacco use is the single most important preventable cause of cancer-related deaths in the USA and many parts of the world. There is growing evidence that menthol cigarettes are starter tobacco products for children, adolescents, and young adults. Accumulating research also suggests that smoking menthol cigarettes reinforces nicotine dependence, impedes cessation, and promotes relapse. However, menthol cigarettes are exempt from the US Food and Drug Administration ban on flavored cigarettes due, in part, to the lack of empirical evidence describing the health consequences of smoking menthol cigarettes relative to regular cigarettes. Determining the biological effects of menthol cigarette smoke relative to regular cigarette smoke can clarify the health risks associated with the use of respective products and assist regulatory agencies in making scientifically based decisions on the development and evaluation of regulations on tobacco products to protect public health and to reduce tobacco use by minors. We highlight the inherent shortcomings of the conventional epidemiologic, clinical, and laboratory research on menthol cigarettes that have contributed to the ongoing debate on the public health impact of menthol in cigarettes. In addition, we provide perspectives on how future investigations exploiting state-of-the-art biomarkers of exposure and disease states can help answer the lingering question of menthol in cigarettes.
\end{abstract}

Keywords Cancer $\cdot$ FDA $\cdot$ Health risk $\cdot$ Tobacco products $\cdot$ Smoke

\footnotetext{
A. Besaratinia $(\bowtie) \cdot S$. Tommasi

Department of Preventive Medicine, Keck School of Medicine, University of Southern California, M/C 9603, Los Angeles, CA 90033, USA

e-mail: besarati@med.usc.edu
}

With the enactment of the Family Smoking Prevention and Tobacco Control Act (FSPTCA) in 2009, the US Food and Drug Administration (FDA) was granted authority to regulate the manufacture, marketing, and distribution of tobacco products to protect public health and to reduce tobacco use by minors [1]. In 2011, the Tobacco Products Scientific Advisory Committee (TPSAC) reported to the FDA that "menthol cigarettes damage public health," and recommended that "removal of menthol cigarettes would benefit public health in the USA" [2]. The TPSAC report has been substantiated by ample research, suggesting that smoking menthol cigarettes is a "gateway" to using other tobacco products, especially during childhood and early adulthood, increases nicotine addiction, deters quitting, and promotes relapse [3,4]. Because smoking is our nation's leading cause of preventable death [5, 6], any ingredient that may encourage people to take up this deadly habit or reinforce this lethal addiction should be considered a significant public health concern. However, the FDA has not yet taken regulatory steps, including imposing a ban on menthol cigarettes despite banning all the other flavored cigarettes from the US market [1]. This lack of action may, in part, be due to the absence of empirical evidence describing the health consequences of smoking menthol cigarettes relative to regular cigarettes [7, 8]. Finding scientific underpinnings for the adverse health effects of smoking menthol cigarettes relative to regular cigarettes is of significance because it can help advance the FDA's mission of developing and evaluating regulations on tobacco products to protect the public's health and to reduce tobacco use by minors [1].

Menthol $\left(\mathrm{C}_{10} \mathrm{H}_{19} \mathrm{OH}\right)$, a monocyclic terpene alcohol derived from both natural and synthetic sources, is used as a flavoring agent in cigarettes and other consumer products [9-11]. Menthol cigarettes are manufactured by spraying 
this additive on tobacco, applying it to the packaging foil, or introducing it into the filter [12]. Menthol cigarettes account for a substantial portion of market share in the USA and many parts of the world; current market shares for mentholated brands include $26 \%$ in the USA, $60 \%$ in the Philippines, 35-40\% in Cameroon, $26 \%$ in Hong Kong, $22 \%$ in Singapore, and 5-10\% in other countries surveyed $[13,14]$. Menthol cigarettes are disproportionally used by certain segments of the population [15]. In the USA, youths, women, and communities of color, particularly, African-Americans, Hispanics, and other racial and ethnic minorities of low income, are preferential users of menthol cigarettes [15-17]. The disparate use of menthol cigarettes by smokers of different gender, race, or ethnicity is thought to contribute, at least, partly to the uneven distribution of tobacco-attributable diseases across populations [18-22]. In support of this theory, over $70 \%$ of African-Americans smoke menthol cigarettes as compared to $30 \%$ of Whites [13, 23, 24], which is consistent with the higher incidence and mortality rates of lung cancer (36 and $31 \%$, respectively) in African-American men than in White counterparts [20, 25]. Also, the death rates from cerebrovascular disease, for which smoking is a major risk factor, are nearly twice as high among African-American men and women as those among White counterparts [21].

However, epidemiologic studies have not unequivocally linked menthol cigarette use as compared to regular cigarette smoking to the disparate burdens of tobacco-attributable diseases in different (sub-) populations [26-28]. Notwithstanding this, epidemiologic tools are too blunt to detect an augmented risk due to the presence of menthol in cigarettes, considering the overwhelming harm associated with smoking any type of tobacco cigarette [29, 30]. Additionally, epidemiologic studies are limited by realworld smoking patterns and the difficulties of identifying smokers who "exclusively" use menthol cigarettes for a long enough period of time to allow meaningful comparisons with non-menthol cigarette smokers [3]. Given the above limitations of the epidemiologic studies [29, 31, 32], it seems unlikely that conventional epidemiologic approaches would unambiguously tie menthol cigarette use to elevated risks of tobacco-related diseases across diverse populations [3, 4].

Likewise, clinical and basic laboratory research is yet to provide compelling empirical evidence that menthol cigarette use indeed causes greater or more severe biological consequences than regular cigarette smoking [4]. For example, clinical investigations of smoke-exposure biomarkers (e.g., serum cotinine or carbon monoxide) or smoking topography (e.g., puff frequency or puff volume) in menthol and non-menthol cigarette smokers have shown inconsistent results, with some reporting higher, some lower, and some comparable levels of the measured biomarkers/indices in the two smoking groups [3, 4]. Similarly, basic laboratory research on the biological effects of menthol and regular cigarette smoke has produced mixed results [4]. Whereas smoke inhalation experiments in rodents have indicated inconsistent tumorigenic effects for menthol cigarettes relative to regular cigarettes [33, 34], in vitro cell culture experiments have shown that menthol increases the permeation of tobacco carcinogen nitrosonornicotine and nicotine across mucous membranes and inhibits cell proliferation, and/or induces cytotoxicity [3, 4]. However, tobacco-industry-associated research has contended that menthol and regular cigarette smoke have similar levels of cytotoxicity in short-term bioassays [35]. Conversely, smoke chemistry studies have shown that the chemical composition of mainstream smoke of selected menthol cigarettes is different from that of nonmenthol cigarettes [36]. Also, chemical analysis of the mainstream smoke of mentholated and regular cigarettes has revealed that menthol increases the yield of total particulate matter, onto which tobacco carcinogens, such as polycyclic aromatic hydrocarbons, and tobacco-specific nitrosamines, are deposited [37]. It is suggested that menthol may also retard nicotine metabolism and interfere with activation or detoxification of smoke toxicants, thus prolonging the existence of addictive, toxic, and/or carcinogenic compounds in the body [4, 38-41]. Furthermore, it is hypothesized that introducing a single agent, such as menthol, to tobacco may cause additional formation of a number of toxic and/or carcinogenic compounds in the smoke, which would not have emerged had menthol not been present [42]. Future clinical studies and basic laboratory research are expected to exploit cutting-edge technologies for biomarker discovery, which will enable robust comparisons of the biological effects of menthol and regular cigarette smoking. It is anticipated that these investigations will monitor state-of-the-art biochemical, cellular, or molecular markers in well-defined populations of menthol and non-menthol cigarette smokers, and also in validated model systems in vitro/in vivo.

Over the past decade, observational studies and clinical trials have increasingly investigated the effects of menthol on smoking initiation, addiction, and cessation [43]. The growing body of evidence supports that the minty and candy-like flavor, aroma, and topical cooling and anesthetic properties of menthol make mentholated cigarettes preferable to those who struggle to overcome their aversion to certain sensations of smoking, such as harshness, throat and chest irritation, and stale aftertaste [44-46]. By easing the discomfort associated with smoking and smoothening the smoking experience, menthol cigarettes may serve as a starter product for youth and young adults, thus helping facilitate the transition from experimentation to regular smoking and addiction [12, 47-49]. Furthermore, menthol 
cigarettes are increasingly shown to promote nicotine dependence and adversely impact smoking cessation, especially among sub-populations of smokers, e.g., African-Americans or women [3, 29, 43, 50, 51]. Recent nationally representative studies in the USA and Canada [49, 51-60] have confirmed earlier reports [61-69] that menthol cigarette use is associated with increased nicotine addiction and reduced cessation success. Other studies, however, failed to demonstrate a significant difference in cessation-related outcomes between menthol and nonmenthol cigarette smokers [26, 70-74]. The latter studies, however, have been criticized for not using sensitive and robust indicators of cessation, e.g., longitudinal abstinence trajectories $[43,51,75]$. In addition, these studies may have been underpowered to detect the effects of menthol, especially, within sub-populations of menthol and nonmenthol cigarette smokers [51, 59]. Altogether, the emerging picture from the majority of the initial investigations and the most recent large-scale studies is that menthol is associated with smoking initiation in children and young adults and a heightened risk of cessation failure among habitual smokers [7, 13, 50].

Within the framework of the FSPTCA, the FDA and National Institutes of Health have formed an interagency partnership to foster research relevant to tobacco regulatory science. Multiple research priorities have been identified, including the impact of tobacco product characteristics, e.g., ingredients, constituents, components, additives, such as flavors, and labeling and marketing, on the initiation, especially among youth and other vulnerable populations, as well as the use (including transition to other tobacco products and multiple use), perceptions, dependence, and toxicity of the conventional and new tobacco products (https://prevention.nih.gov/tobacco-regulatory-science-pro gram/research-priorities). The ongoing research and future investigations on these topics are expected to provide a compelling weight of evidence that can be used to inform the general public, scientific community, and regulatory authorities of the health risks/benefits associated with the use of various tobacco products, including menthol cigarettes. Not only this information will help generate further interests for scientists in the field of tobacco research, but it will also assist the regulatory agencies in developing and evaluating regulations on tobacco products to protect the public's health and to reduce tobacco use by impressionable teens and other vulnerable groups. The hope is that the studies supported by the FDA/NIH initiative will address the outstanding questions regarding the issue of menthol in cigarettes once and for all.

Acknowledgments We would like to thank Dr. Jonathan M. Samet for his invaluable comments and thoughtful suggestions on our ongoing research on tobacco carcinogenesis. Work of the authors is supported by Grants from the American Cancer Society (RSG-11083-01-CNE) and the University of California Tobacco- Related Disease Research Program (20XT-0116) to A.B. The sponsor of the study had no role in study design, data collection, data analysis, data interpretation, writing of the report, or the decision to submit for publication.

Conflict of interest All the authors declare no conflict of interest.

\section{References}

1. Family Smoking Prevention and Tobacco Control Act, Public Law 111-31, 123 Stat. 1776 (22 June 2009) (2009). http://www. fda.gov/downloads/TobaccoProducts/GuidanceCompliance RegulatoryInformation/UCM237080.pdf

2. Tobacco Products Scientific Advisory Committee (TPSAC) (2011) Menthol cigarettes and public health: review of the scientific evidence and recommendations. Center for Tobacco Products, Food and Drug Administration, Rockville. http://www.fda. gov/downloads/AdvisoryCommittees/committeesmeetingmaterials/ tobaccoproductsScientificAdvisoryCommittee/UCM247689.pdf

3. Gardiner P, Clark PI (2010) Menthol cigarettes: moving toward a broader definition of harm. Nicotine Tob Res 12(Suppl 2):S85S93. doi:10.1093/ntr/ntq176

4. Hoffman AC (2011) The health effects of menthol cigarettes as compared to non-menthol cigarettes. Tob Indu Dis 9(Suppl 1):S7. doi:10.1186/1617-9625-9-S1-S7

5. Centers for Disease Control and Prevention (CDC) (2008) Smoking-attributable mortality, years of potential life lost, and productivity losses-United States, 2000-2004. Morbidity and mortality weekly report (MMWR). http://www.cdc.gov/mmwr/ pdf/wk/mm5745.pdf

6. The US Surgeon General (2014) The health consequences of smoking-50 years of progress: a report of the surgeon general. US Department of health and human services, Centers for disease control and prevention, national center for Chronic disease prevention and health promotion, office on smoking and health. http://www.surgeongeneral.gov/library/reports/50-years-of-progress/

7. Benowitz NL, Samet JM (2011) The threat of menthol cigarettes to US public health. N Engl J Med 364(23):2179-2181. doi:10. 1056/NEJMp1103610

8. Mitka M (2013) FDA might consider restrictions on menthol cigarettes. JAMA 310(8):784. doi:10.1001/jama.2013.276273

9. Eccles R (1994) Menthol and related cooling compounds. J Pharm Pharmacol 46(8):618-630

10. Green BG (1986) Menthol inhibits the perception of warmth. Physiol Behav 38(6):833-838

11. Sant'Ambrogio FB, Anderson JW, Sant'Ambrogio G (1991) Effect of 1-menthol on laryngeal receptors. J Appl Physiol 70(2):788-793

12. Hersey JC, Nonnemaker JM, Homsi G (2010) Menthol cigarettes contribute to the appeal and addiction potential of smoking for youth. Nicotine Tob Res 12(Suppl 2):S136-S146. doi:10.1093/ntr/ntq173

13. Giovino GA, Sidney S, Gfroerer JC, O'Malley PM, Allen JA, Richter PA, Cummings KM (2004) Epidemiology of menthol cigarette use. Nicotine Tob Res 6(Suppl 1):S67-S81. doi:10. 1080/14622203710001649696

14. King B, White V, Balmford J, Cooper J, Borland R (2012) The decline of menthol cigarette smoking in Australia, 1980-2008. Nicotine Tob Res 14(10):1213-1220. doi:10.1093/ntr/nts073

15. Caraballo RS, Asman K (2011) Epidemiology of menthol cigarette use in the United States. Tob Induc Dis 9(Suppl 1):S1. doi:10.1186/1617-9625-9-S1-S1 
16. Lawrence D, Rose A, Fagan P, Moolchan ET, Gibson JT, Backinger CL (2010) National patterns and correlates of mentholated cigarette use in the United States. Addiction 105(Suppl 1):13-31. doi:10.1111/j.1360-0443.2010.03203.x

17. Giovino GA (2010) Patterns of and recent trends in use of mentholated cigarettes in the United States. Paper presented at the FDA tobacco products scientific advisory committee meeting, Silver Spring

18. Hebert JR, Kabat GC (1988) Menthol cigarettes and esophageal cancer. Am J Public Health 78(8):986-987

19. Wagenknecht LE, Cutter GR, Haley NJ, Sidney S, Manolio TA, Hughes GH, Jacobs DR (1990) Racial differences in serum cotinine levels among smokers in the coronary artery risk development in (Young) adults study. Am J Public Health 80(9):1053-1056

20. Richardson TL (1997) African-American smokers and cancers of the lung and of the upper respiratory and digestive tracts. Is menthol part of the puzzle? West J Med 166(3):189-194

21. Centers for Disease Control and Prevention (CDC) (1998) Tobacco use among U.S. Racial/Ethnic minority groups-African Americans, American Indians and Alaska natives, Asian Americans and Pacific Islanders, and Hispanics: A report of the surgeon general. morbidity and mortality weekly report (MMWR). http://profiles.nlm.nih.gov/ps/access/NNBBFQ.pdf

22. Garten S, Falkner RV (2004) Role of mentholated cigarettes in increased nicotine dependence and greater risk of tobaccoattributable disease. Prev Med 38(6):793-798. doi:10.1016/j. ypmed.2004.01.019

23. Gardiner PS (2004) The African Americanization of menthol cigarette use in the United States. Nicotine Tob Res 6(Suppl 1):S55-S65. doi:10.1080/14622200310001649478

24. US Department of Commerce, Census Bureau (2012) National cancer institute-sponsored tobacco use supplement to the current population survey (2010-2011). http://appliedresearch.cancer. gov/tus-cps/. Data files and technical documentation: http://the dataweb.rm.census.gov/ftp/cps_ftp.html\#cpssupps

25. American Cancer Society (ACS) (2013) Cancer facts and figures 2013. Atlanta

26. Blot WJ, Cohen SS, Aldrich M, McLaughlin JK, Hargreaves MK, Signorello LB (2011) Lung cancer risk among smokers of menthol cigarettes. J Natl Cancer Inst 103(10):810-816. doi:10.1093/ jnci/djr102

27. Rostron B (2012) Lung cancer mortality risk for US menthol cigarette smokers. Nicotine Tob Res 14(10):1140-1144. doi:10. 1093/ntr/nts014

28. Jones MR, Tellez-Plaza M, Navas-Acien A (2013) Smoking, menthol cigarettes and all-cause, cancer and cardiovascular mortality: evidence from the National Health and Nutrition Examination Survey (NHANES) and a meta-analysis. PLoS One 8(10):e77941. doi:10.1371/journal.pone.0077941

29. Clark PI, Gardiner P (2011) Menthol should not be given a free pass based on studies of biomarkers of toxicity. Cancer Epidemiol Biomark Prev 20(7):1269-1271. doi:10.1158/1055-9965. EPI-11-0410

30. Muscat JE (2012) Menthol cigarettes and lung cancer mortality. Nicotine Tob Res 14(10):1246-1247. doi:10.1093/ntr/nts156. Author reply 1248

31. Brooks DR, Palmer JR, Strom BL, Rosenberg L (2003) Menthol cigarettes and risk of lung cancer. Am $\mathrm{J}$ Epidemiol 158(7):609-616 discussion 617-620

32. Clark PI, Gardiner PS, Djordjevic MV, Leischow SJ, Robinson RG (2004) Menthol cigarettes: setting the research agenda. Nicotine Tob Res 6(Suppl 1):S5-S9. doi:10.1080/1462220031000 1649441
33. Wattenberg LW (1991) Inhibition of azoxymethane-induced neoplasia of the large bowel by 3-hydroxy-3,7,11-trimethyl1,6,10-dodecatriene (nerolidol). Carcinogenesis 12(1):151-152

34. Gaworski CL, Dozier MM, Gerhart JM, Rajendran N, Brennecke LH, Aranyi C, Heck JD (1997) 13-week inhalation toxicity study of menthol cigarette smoke. Food Chem Toxicol 35(7):683-692

35. Heck JD (2010) A review and assessment of menthol employed as a cigarette flavoring ingredient. Food Chem Toxicol 48(Suppl 2):S1S38. doi:10.1016/j.fct.2009.11.002

36. Borgerding MF, Bodnar JA, Wingate DE (2000) The 1999 Massachusetts benchmark study: final report. http://legacy. library.ucsf.edu/documentStore/y/e/k/yek21c00/Syek21c00.pdf

37. Gordon SM, Brinkman MC, Meng RQ, Anderson GM, Chuang JC, Kroeger RR, Reyes IL, Clark PI (2011) Effect of cigarette menthol content on mainstream smoke emissions. Chem Res Toxicol 24(10):1744-1753. doi:10.1021/tx200285s

38. Benowitz NL, Herrera B, Jacob P 3rd (2004) Mentholated cigarette smoking inhibits nicotine metabolism. J Pharmacol Exp Ther 310(3):1208-1215. doi:10.1124/jpet.104.066902

39. MacDougall JM, Fandrick K, Zhang X, Serafin SV, Cashman JR (2003) Inhibition of human liver microsomal (S)-nicotine oxidation by (-)-menthol and analogues. Chem Res Toxicol 16(8):988-993. doi:10.1021/tx0340551

40. Muscat JE, Chen G, Knipe A, Stellman SD, Lazarus P, Richie JP Jr (2009) Effects of menthol on tobacco smoke exposure, nicotine dependence, and NNAL glucuronidation. Cancer Epidemiol Biomark Prev 18(1):35-41. doi:10.1158/1055-9965.EPI-08-0744

41. Benowitz NL (2008) Clinical pharmacology of nicotine: implications for understanding, preventing, and treating tobacco addiction. Clin Pharmacol Ther 83(4):531-541. doi:10.1038/clpt. 2008.3

42. Henningfield JE, Djordjevic MV (2004) Menthol cigarettes: research needs and challenges. Nicotine Tob Res 6(Suppl 1):S11S16. doi:10.1080/14622200310001649450

43. Hoffman AC, Simmons D (2011) Menthol cigarette smoking and nicotine dependence. Tob Induc Dis 9(Suppl 1):S5. doi:10.1186/ 1617-9625-9-S1-S5

44. Ferris Wayne G, Connolly GN (2004) Application, function, and effects of menthol in cigarettes: a survey of tobacco industry documents. Nicotine Tob Res 6(Suppl 1):S43-S54. doi:10.1080/ 14622203310001649513

45. Kreslake JM, Wayne GF, Connolly GN (2008) The menthol smoker: tobacco industry research on consumer sensory perception of menthol cigarettes and its role in smoking behavior. Nicotine Tob Res 10(4):705-715. doi:10.1080/146222008019 79134

46. Kreslake JM, Yerger VB (2010) Tobacco industry knowledge of the role of menthol in chemosensory perception of tobacco smoke. Nicotine Tob Res 12(Suppl 2):S98-S101. doi:10.1093/ ntr/ntq208

47. Healton CG, Bullock AT, Robinson WS, Beck SE, Cartwright J, Eubanks SY (2010) Why we should make menthol cigarettes history. Nicotine Tob Res 12(Suppl 2):S94-S97. doi:10.1093/ntr/ ntq177

48. Kreslake JM, Wayne GF, Alpert HR, Koh HK, Connolly GN (2008) Tobacco industry control of menthol in cigarettes and targeting of adolescents and young adults. Am J Public Health 98(9):1685-1692. doi:10.2105/AJPH.2007.125542

49. Rosenbloom J, Rees VW, Reid K, Wong J, Kinnunen T (2012) A cross-sectional study on tobacco use and dependence among women: does menthol matter? Tob Indu Dis 10(1):19. doi:10. 1186/1617-9625-10-19

50. Lee YO, Glantz SA (2011) Menthol: putting the pieces together. Tob Control 20(Suppl 2):ii1-ii7. doi:10.1136/tc.2011.043604 
51. Smith SS, Fiore MC, Baker TB (2014) Smoking cessation in smokers who smoke menthol and non-menthol cigarettes. Addiction. doi:10.1111/add.12661

52. Ahijevych K, Ford J (2010) The relationships between menthol cigarette preference and state tobacco control policies on smoking behaviors of young adult smokers in the 2006-2007 Tobacco Use Supplements to the Current Population Surveys (TUS CPS). Addiction 105(Suppl 1):46-54. doi:10.1111/j.1360-0443.2010. 03201.x

53. Trinidad DR, Perez-Stable EJ, Messer K, White MM, Pierce JP (2010) Menthol cigarettes and smoking cessation among racial/ ethnic groups in the United States. Addiction 105(Suppl 1):84-94. doi:10.1111/j.1360-0443.2010.03187.x

54. Fagan P, Moolchan ET, Hart A Jr, Rose A, Lawrence D, Shavers VL, Gibson JT (2010) Nicotine dependence and quitting behaviors among menthol and non-menthol smokers with similar consumptive patterns. Addiction 105(Suppl 1):55-74. doi:10. 1111/j.1360-0443.2010.03190.x

55. Stahre M, Okuyemi KS, Joseph AM, Fu SS (2010) Racial/ethnic differences in menthol cigarette smoking, population quit ratios and utilization of evidence-based tobacco cessation treatments. Addiction 105(Suppl 1):75-83. doi:10.1111/j.1360-0443.2010. 03200.x

56. Levy DT, Blackman K, Tauras J, Chaloupka FJ, Villanti AC, Niaura RS, Vallone DM, Abrams DB (2011) Quit attempts and quit rates among menthol and nonmenthol smokers in the United States. Am J Public Health 101(7):1241-1247. doi:10.2105/ AJPH.2011.300178

57. Delnevo CD, Gundersen DA, Hrywna M, Echeverria SE, Steinberg MB (2011) Smoking-cessation prevalence among US smokers of menthol versus non-menthol cigarettes. Am J Prev Med 41(4):357-365. doi:10.1016/j.amepre.2011.06.039

58. Nonnemaker J, Hersey J, Homsi G, Busey A, Allen J, Vallone D (2013) Initiation with menthol cigarettes and youth smoking uptake. Addiction 108(1):171-178. doi:10.1111/j.1360-0443. 2012.04045.x

59. Azagba S, Minaker LM, Sharaf MF, Hammond D, Manske S (2014) Smoking intensity and intent to continue smoking among menthol and non-menthol adolescent smokers in Canada. Cancer Causes Control 25(9):1093-1099. doi:10.1007/s10552-014-0410-6

60. Lewis M, Wang Y, Berg CJ (2014) Tobacco control environment in the United States and individual consumer characteristics in relation to continued smoking: differential responses among menthol smokers? Prev Med 65:47-51. doi:10.1016/j.ypmed. 2014.04.019

61. Okuyemi KS, Ebersole-Robinson M, Nazir N, Ahluwalia JS (2004) African-American menthol and nonmenthol smokers: differences in smoking and cessation experiences. J Natl Med Assoc 96(9):1208-1211

62. Harris KJ, Okuyemi KS, Catley D, Mayo MS, Ge B, Ahluwalia JS (2004) Predictors of smoking cessation among African-
Americans enrolled in a randomized controlled trial of bupropion. Prev Med 38(4):498-502. doi:10.1016/j.ypmed.2003.12.008

63. Pletcher MJ, Hulley BJ, Houston T, Kiefe CI, Benowitz N, Sidney S (2006) Menthol cigarettes, smoking cessation, atherosclerosis, and pulmonary function: the Coronary Artery Risk Development in Young Adults (CARDIA) Study. Arch Intern Med 166(17):1915-1922. doi:10.1001/archinte.166.17.1915

64. Hersey JC, Ng SW, Nonnemaker JM, Mowery P, Thomas KY, Vilsaint MC, Allen JA, Haviland ML (2006) Are menthol cigarettes a starter product for youth? Nicotine Tob Res 8(3):403-413. doi:10.1080/14622200600670389

65. Collins CC, Moolchan ET (2006) Shorter time to first cigarette of the day in menthol adolescent cigarette smokers. Addict Behav 31(8):1460-1464. doi:10.1016/j.addbeh.2005.10.001

66. Okuyemi KS, Faseru B, Sanderson LC, Bronars CA, Ahluwalia JS (2007) Relationship between menthol cigarettes and smoking cessation among African American light smokers. Addiction 102(12):1979-1986. doi:10.1111/j.1360-0443.2007.02010.x

67. Wackowski O, Delnevo CD (2007) Menthol cigarettes and indicators of tobacco dependence among adolescents. Addict Behav 32(9):1964-1969. doi:10.1016/j.addbeh.2006.12.023

68. Gandhi KK, Foulds J, Steinberg MB, Lu SE, Williams JM (2009) Lower quit rates among African American and Latino menthol cigarette smokers at a tobacco treatment clinic. Int J Clin Pract 63(3):360-367. doi:10.1111/j.1742-1241.2008.01969.x

69. Gundersen DA, Delnevo CD, Wackowski O (2009) Exploring the relationship between race/ethnicity, menthol smoking, and cessation, in a nationally representative sample of adults. Prev Med 49(6):553-557. doi:10.1016/j.ypmed.2009.10.003

70. Muscat JE, Richie JP Jr, Stellman SD (2002) Mentholated cigarettes and smoking habits in whites and blacks. Tob Control 11(4):368-371

71. Hyland A, Garten S, Giovino GA, Cummings KM (2002) Mentholated cigarettes and smoking cessation: findings from COMMIT. Community Intervention Trial for Smoking Cessation. Tob Control 11(2):135-139

72. Murray RP, Connett JE, Skeans MA, Tashkin DP (2007) Menthol cigarettes and health risks in lung health study data. Nicotine Tob Res 9(1):101-107. doi:10.1080/14622200601078418

73. Fu SS, Okuyemi KS, Partin MR, Ahluwalia JS, Nelson DB, Clothier BA, Joseph AM (2008) Menthol cigarettes and smoking cessation during an aided quit attempt. Nicotine Tob Res 10(3):457-462. doi:10.1080/14622200801901914

74. Cubbin C, Soobader MJ, LeClere FB (2010) The intersection of gender and race/ethnicity in smoking behaviors among menthol and non-menthol smokers in the United States. Addiction 105(Suppl 1):32-38. doi:10.1111/j.1360-0443.2010.03191.x

75. Lee JH, Herzog TA, Meade CD, Webb MS, Brandon TH (2007) The use of GEE for analyzing longitudinal binomial data: a primer using data from a tobacco intervention. Addict Behav 32(1):187-193. doi:10.1016/j.addbeh.2006.03.030 